\title{
Measurements and Simulations of Ozone and Precursors in Greater Berlin during a Period of Summer Smog in July 1994
}

\author{
Prof. Dr. sc. nat. Bernd Stark, Dipl.-Met. Martin Lutz
}

\section{Introduction}

The frequent overstepping of ozone boundary thresholds and the ensuing discussions as to whether and in what way regional measures designed to limit emissions of ozone precursers could contribute to a reduction in ozone production were to starting point for a measuring project initiated by the governments of the two federal states in the Berlin-Brandenburg region. The structure of emissions in the region and the latter's weak orographic structure, with comparatively simple air current patterns, make this region a nearly ideal area for an investigation of the links between ozone formation and emission of ozone precursors.

The purpose of the project was in the first instance to improve knowledge of the chemical and meteorological processes which cause the formation of high ozone concentrations, and also to assess the effectiveness of regional emissions-reducing measures by means of photochemical model calculations.

The measuring campaign took place from 23. to 27.7.94 during a period of high summer fair weather and pratically ideal meteorological conditions. Measurements of ozone, nitrogen oxide and hydrocarbons concentrations were taken from 2 aircrafts and on the ground using the regional measuring networks, mobile measurings vehicles and observatories. One of the both aircrafts was equipped with instruments which allowed to measure the meteorological parameters wind, temperature, and moisture. The measurements were complemented by radio sonde ascents in the city and in the surrounding area in order to determine air currents, and by windprofiler measurements, ozone sonde ascents and Brewer spectrometer measurements taken from ground level and by SODAR measurements in and on the borders of the city. In addition $\mathrm{H}_{2} \mathrm{O}_{2}$ measurements were carried out at a measuring tower station with a height of $324 \mathrm{~m}$ in the north of Berlin, and air samples were taken in order to ascertain VOC concentrations (Stark, B., et al, 1995).

\section{Pollutants measurements results}

The measuring campaign of 23. to 27.7.94 was undertaken during the first phase of a long period of high summer weather, with a series of 11 so-called 'hot days' with temperatures of over $300 \mathrm{C}$, such as had not been observed in the Berlin area before.

The prevailing air currents during the first three days were east to south-east, with low humidity and typically continental air mass. On the morning of 26.7. the wind turned to north-west, and more humid, subtropical air mass with a higher concentration of emissions entered the area.
For the four days of the campaign each plane made on average one flight in the morning and one flight in the afternoon.

The use of both ascending and descending flights made it possible to measure the vertical structure of the pollutant concentration. It was possible to confirm observations already made by using the BLUME tower station in Berlin-Frohnau (324 m high), that in the early hours of the day ozone concentration increases with height in the first hundred meters above ground level. Due to vertical transport, this ozone reservoir is largely responsible for the increasing ozone values near ground level during the morning.

A time series plot of the measured parameters is given for the afternoon of 27.7.94 in Figure 1.

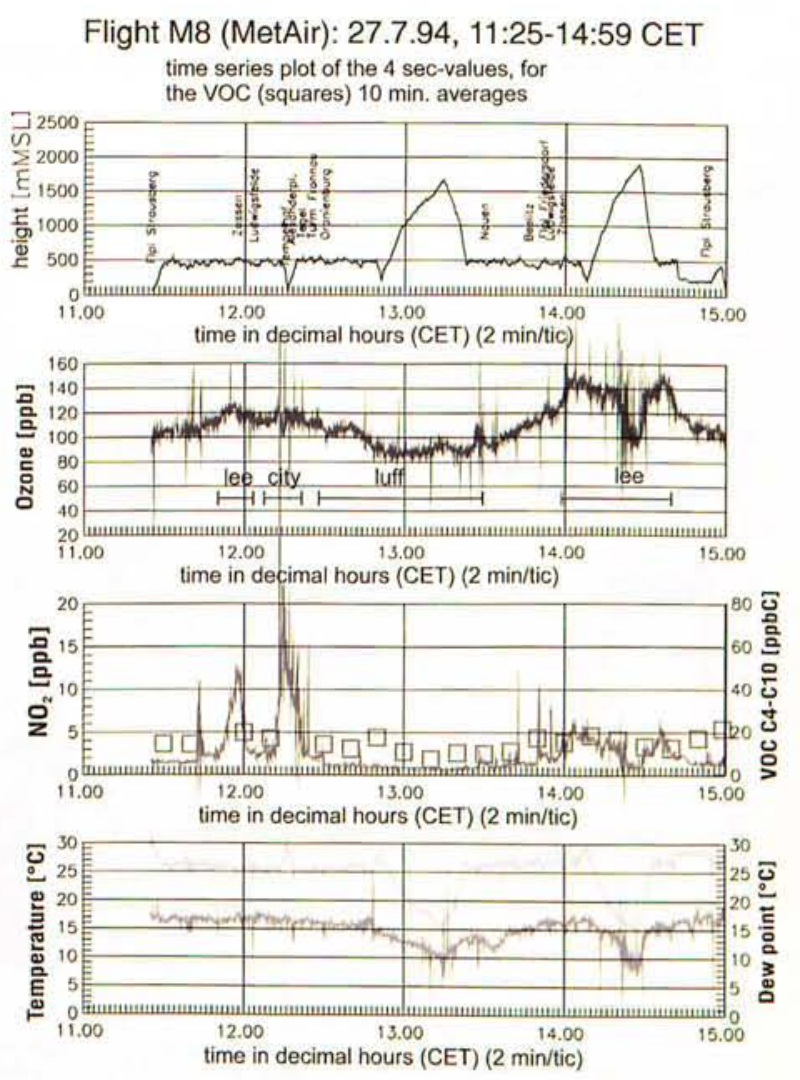

Fig. 1 Time series plot of the measured parameters for the afternoon of 27.7.94.

The spatial distribution of the ozone, $\mathrm{NO}_{2}$ and $\mathrm{VOC}$ concentration is shown in Figures 2 to 4 . The wind direction is indicated by arrows, showing that there is a considerable increase in ozone concentration to the lee side of Berlin. On the 25.7.94 and the preceding days lee was north west of the town, whereas the turning wind to NW-N on the 27.7.94 meant that Berlin's southern regions were affected by ozone increase. 


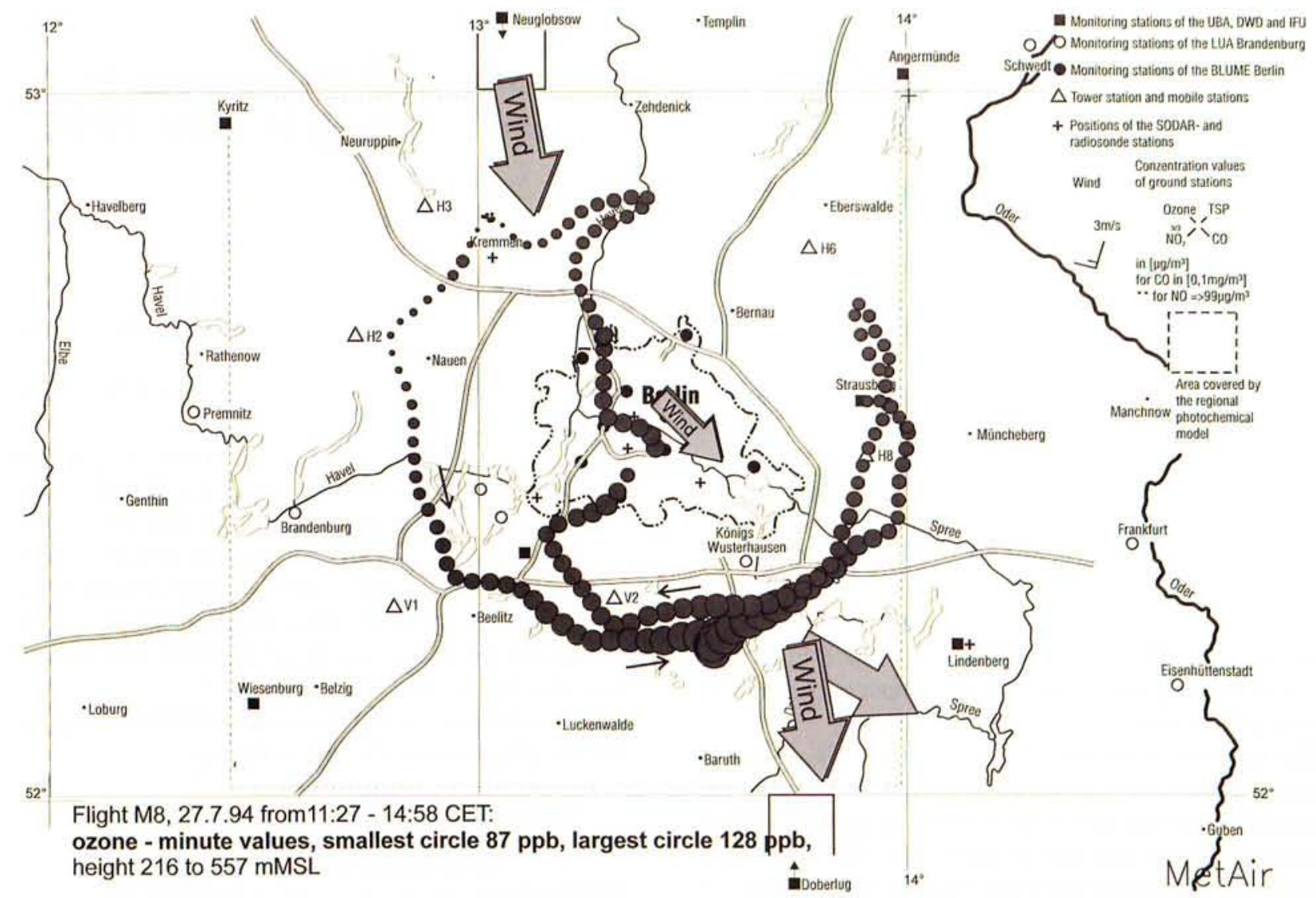

Fig. 2 Aircraft measurement of the spatial distribution of the ozone concentration on 27.7.94

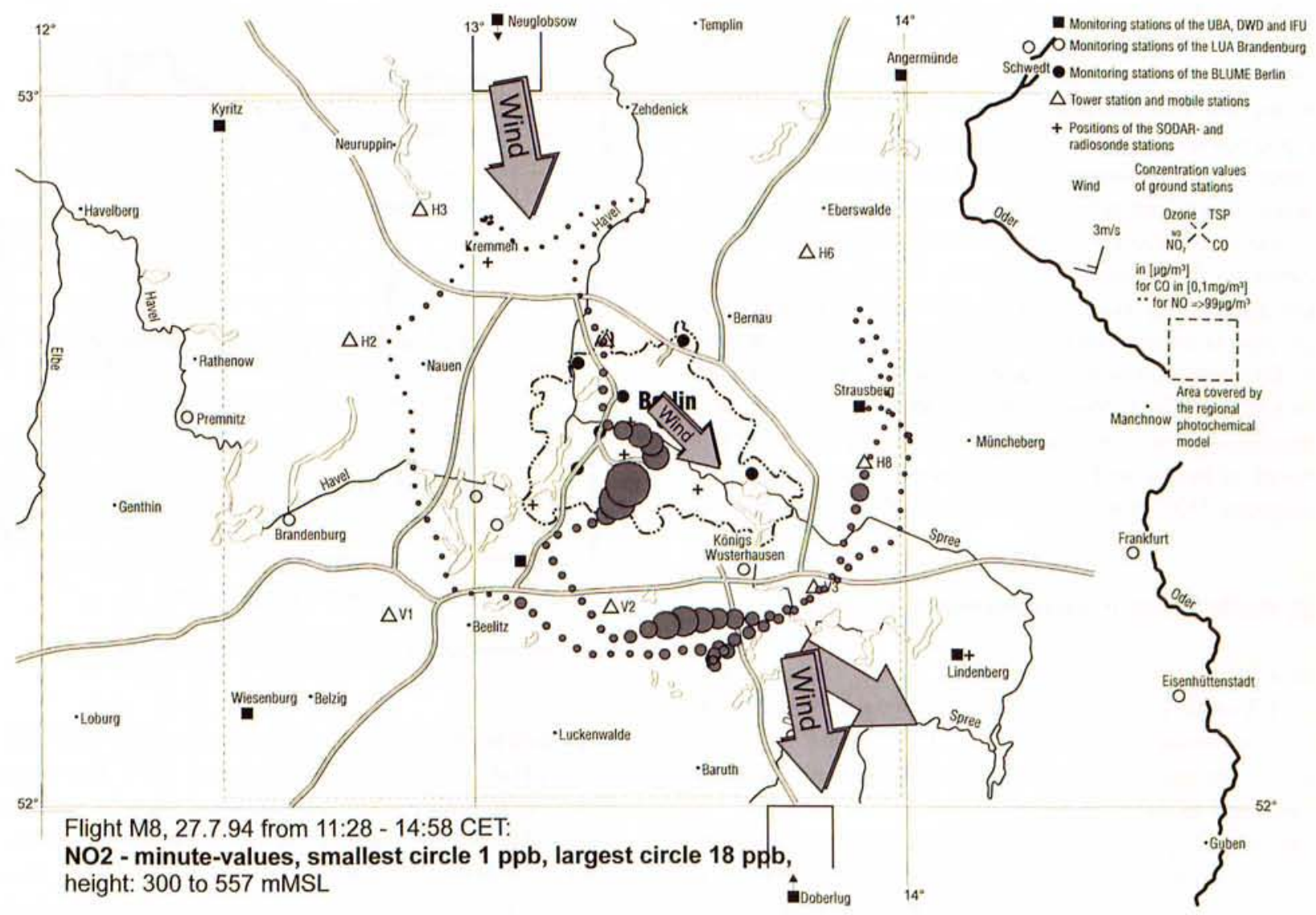

Fig. 3 Aircraft measurement of the spatial distribution of the $\mathrm{NO}_{2}$-concentration on 27.7.94 


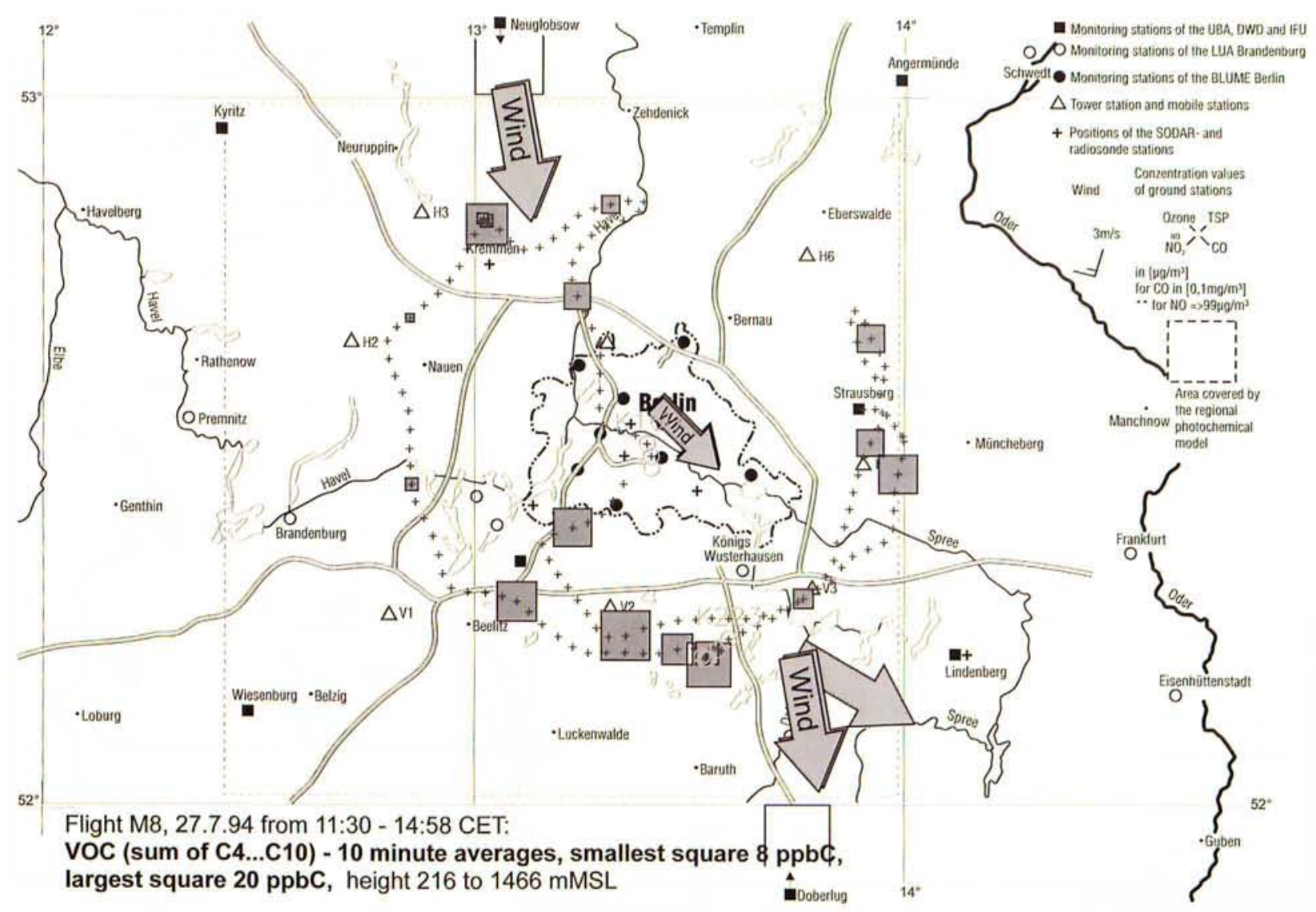

Fig. 4 Aircraft measurement of the spatial distribution of the total VOC-concentration (sum of C4... C10) on 27.7.94

In areas close to the source of nitrogen oxide, maximum levels of $\mathrm{NO}_{2}$ concentration result in minimum ozone levels, because the former initially causes the latter to decompose, whereas both ozone and $\mathrm{NO}_{2}$ concentrations increase in the plume (Fig. 1).

Figure 5 shows the pollutants distribution of several pollutants at ground level, as measured at the same time by using additional mobile measuring vehicles. Decreasing ozone levels in the city centre due to higher NOx emissions stand in clear contrast to a considerable increase beginning at the southern city limits.

Figure 6 gives the ozone levels in luff and lee for all afternoon flights, as measured by MetAir aircraft. The lee effect decreases from 23. to 25.7. because of the increasing size of the convective boundary layer and the greater wind speed on the 24.7. This effect is considerably weaker than during the final two days of the campaign, during which an increase of ozone concentration of up to $44 \%$ more than the luff level was observed.

As part of the project it was attempted to establish total and differentiated levels of VOCs which to a considerable degree contribute to the formation of ozone. In order to determine the total VOC levels detailed analyses of random samples of a total of 36 single substances of the molecular groups C2 to C8 were combined with continuous mesurements of the total mass of molecular groups C4 (using a $\mathrm{HC1} 1010$ gas chromatograph in the MetAir aircraft) and C6 (using a HC1010 gas chromatograph on the Frohnau radio tower) to $\mathrm{C} 10$ and also with measurements of the total hydrocarbons without methane in the inner city of Berlin. The possible inaccuracy of these results is estimated to be
$30 \%$ at high concentrations, and a factor of 2 at low concentrations.

The measurements showed that hydrocarbon pollution in the city air, with concentrations 200 to $600 \mathrm{ppbC}$, was much greater than in the surrounding area, where 50 to $100 \mathrm{ppbC}$ were measured in the city plume and 20 to $50 \mathrm{ppbC}$ in the air near ground level, which was not influenced by the city air. In the free atmosphere levels of 10 to $50 \mathrm{ppbC}$ of organic compounds were noted in the convective boundary layer (to about $1500 \mathrm{~m}$ in height) beyond the city plum, and above the convective boundary layer these levels were less than $10 \mathrm{ppbC}$.

The total VOCs (Fig. 4) show less difference between luff and lee than for $\mathrm{NO}_{2}$, however. This is due to the significant amount of isoprene emitted over a broad area outside the city and to the differing reactivity of the substances emitted within the city boundary. The detailed random sample analyses prove that the VOC mixture in the city air contains considerably more reactive components than in the surrounding areas. Figure 7 shows the proportion of different VOC substances, split into the areas 'city', 'luff', 'lee' and 'background' using the relationship of the total VOCs (without ethane and isoprene) to ethane. The measurements thus directly demonstrate that chemical processes take place during transport and dispersion of the pollutants.

By combining all the available measurements it was possible to reconstruct the wind field and concentration distribution over Greater Berlin for the periode of the measuring campaign (Lehning, M., 1995). Balance boxes were set up along the flight routes for the area under observation. The ozone and nitrogen oxide fluxes 


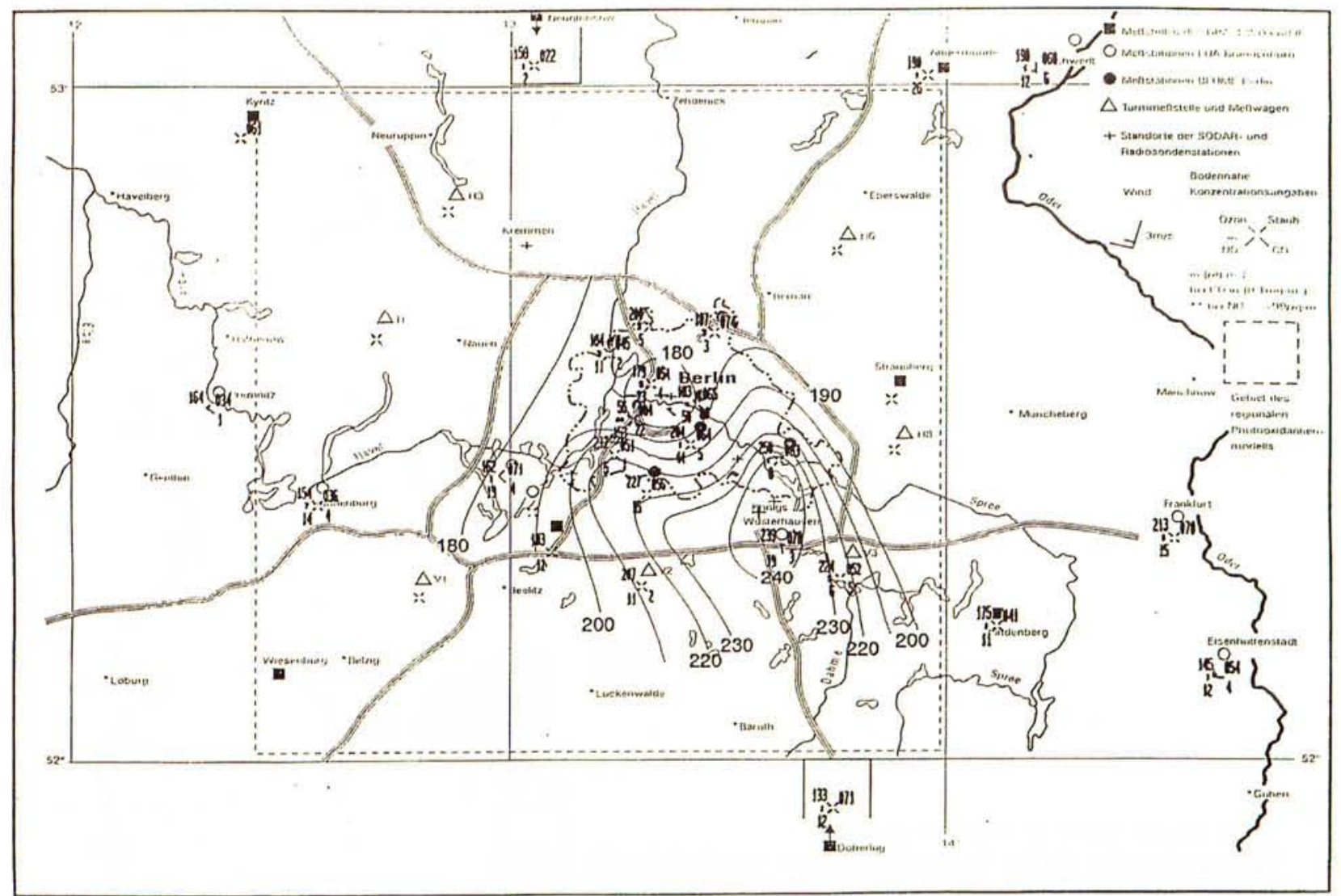

Fig. 5 Spatial distribution of several pollutants (with isolines for ozone) at ground level on 27.7.94

through the walls of these closed boxes were calculated by using the wind and concentration values for the times of the morning and afternoon flights. Thus it was possible to quantify the net production rates, accumulation rates and the export loads for ozone and nitrogen oxide. The ozone accumulation in the afternoon, being the amount of ,home-produced“ ozone, is at a level of between 5 and $30 \%$ according to conditions.

\section{Photochemical Model Calculations}

In order to assess the possible effectiveness of regional emissions-reducing measures on the formation of ozone in the region simulation calculations for ozone formation were carried out. The REGOZON (Mieth, P.,

\section{Ozone levels measured by aeroplane}

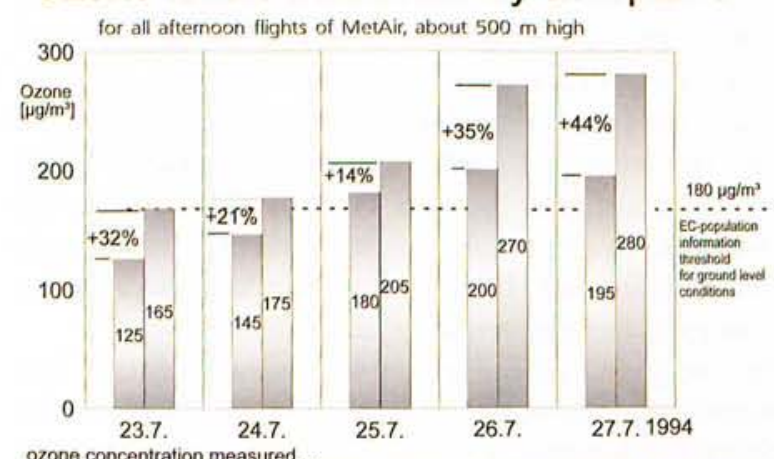

$\square$ in luff of Berlin

$\square$ in lee of Berlin

Figure 6

Fig. 6 Temporal evolution of the ozone levels in luff and lee of the city of Berlin during the campaign measured by aircraft et al, 1992, 1993) simulation model was used. The basis of this model is a three-layered mesoscalic flow and transport model and the chemical reaction mechanism CBM-IV. With an equidistant grid distance of $2 \mathrm{~km}$ and a model area size of approx. $10000 \mathrm{~km}^{2}$ the computation grid has $50 \times 54$ grid points.

The simulations confirmed in the main the existence of considerable ozone production in the area investigated, caused by the human emissions of ozone precursor substances in the built-up area of Berlin. Maximum ozone concentration is attained in the plum of the city at some distance from the centre (Fig. 8). The model results are confirmed by the measurements of ground level pollutants distribution, as shown in Figure 5. The simulation of ozone pollution with a reduction in emissions (scenarios) was carried out on 25. and 27. 7.. On these two days there were different meteorological

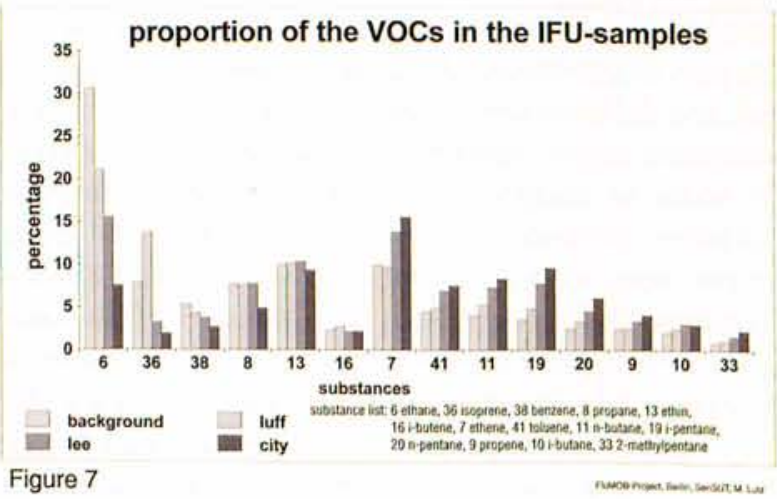

Fig. 7 Proportion of different VOC substances to the sum of 36 VOCs (C2... C8) measured as background, in luff and lee and in the city 


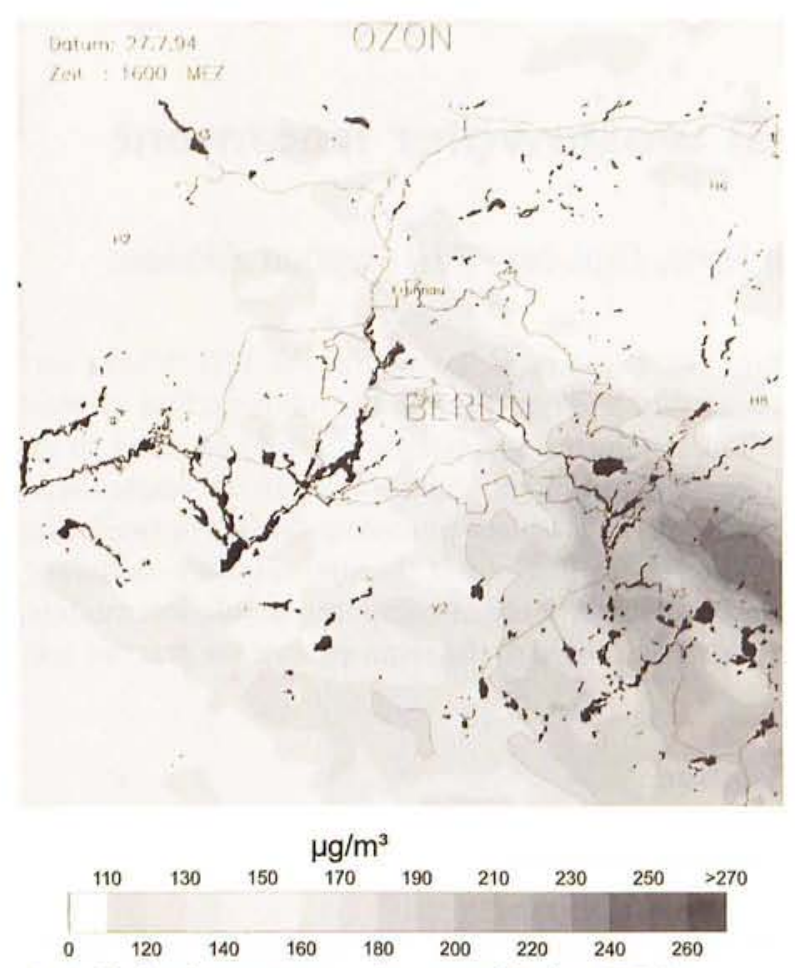

Fig. 8 Simulated ozone concentration at ground level on 27.7.94

conditions. On 25.7. there was a typically continental air mass and the convective boundary layer was nearly $3800 \mathrm{~m}$ high, but on 27.7. there was a more humid and more typically subtropical air mass with a considerably smaller convective boundary layer. The reduction in emissions of about $30 \%$ for NOx and VOC, respectively, was due to preventive measures and prognoses of effects, which could be implemented as acute measures for the area under investigation as a part of summer smog regulations. The results of the simulations are shown in Figures 9 and 10, for the two days during which identical emissions-reducing measures were implemented. The diagrams show that identical preventive steps do not necessarily have identical results under different meteorological conditions. On 25.7. the number of grid cells with more than $180 \mu \mathrm{g} / \mathrm{m}^{3}$ ozone is reduced by nearly $60 \%$, on the 27.7 . by only $4 \%$, whereas the maximum ozone levels in the city plume decreated in both cases less than $10 \%$.

\section{References}

Stark, B., M. Lutz, H.-J. Abraham, P. Lenschow, W. Reichenbächer, E. Reimer and B. Scherer (1995): Flugzeug- und Bodenmessungen von Ozon und Vorläuferstoffen zur Abschätzung der Wirksamkeit von emissionsmindernden Maßnahmen im Großraum BerlinBrandenburg.

Final report by order of the Senate Administration for Urban Development and Environmental Protection, Berlin and the Ministry for Environment, Nature Conservation and Regional Planing of the Brandenburg State

Lehning, M. (1995):

Schadstoffbilanzen mit Sensitivitätsstudie. Report of MetAir for the FluMOB-Project

Mieth, P. and S. Unger (1992):
27.7.94, 16.00 CET

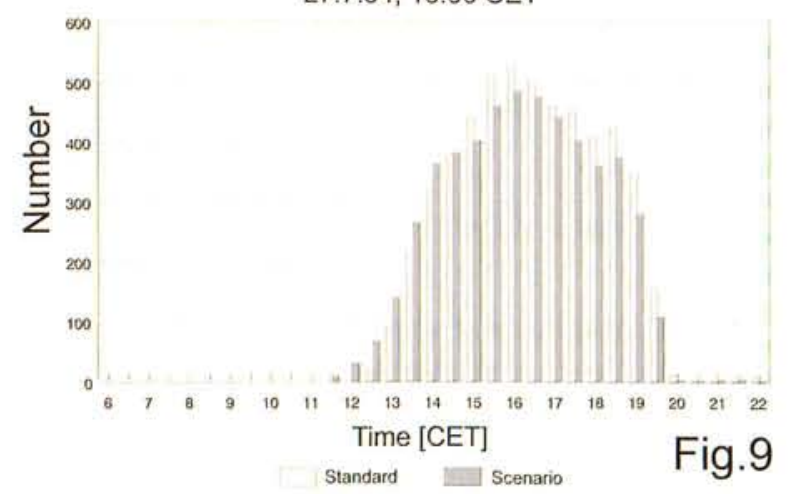

Number of grid cells with ozone concentration $>180 \mu \mathrm{g} / \mathrm{m}^{3}$

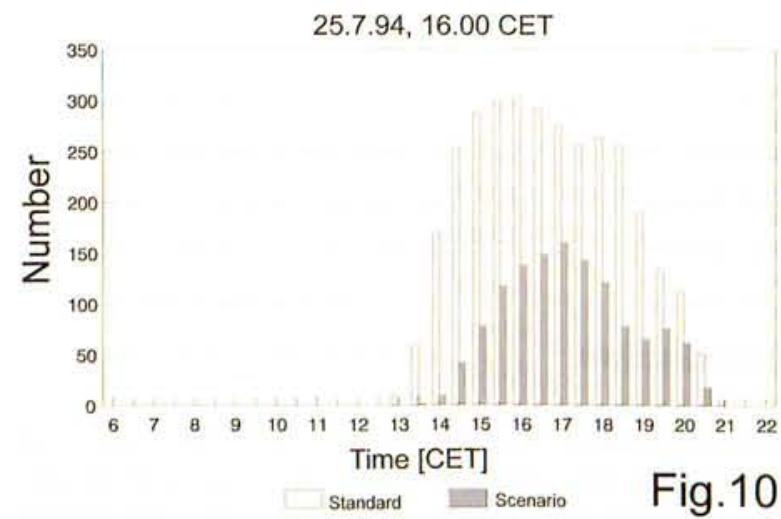

Number of grid cells with ozone concentration $>180 \mu \mathrm{g} / \mathrm{m}^{3}$

Fig. 9 Number of grid cells with ozone concentration nin $180 \mathrm{ig} / \mathrm{m} 3$ for the case simulation with $30 \%$ reduction in emissions of NO2 and VOC (scenario) and the case standard without reduction in emissions on 27.7. with smaller convective boundary layer.

Fig. 10 Number of grid cells with ozone concentration ñ $180 \mathrm{ig} / \mathrm{m} 3$ for the case simulation with $30 \%$ reduction in emissions of NO2 and VOC (scenario) and the case standard without reduction in emissions on 25.5. with high convective boundary layer.

Zum Einfluß der Reduktion von Emissionen verschiedener Emittenten auf die Ozonbildung.

GMD First by order of the Senat Administration for Urban Development and Environmental Protection, Berlin

Mieth, P. and S. Unger:

Szenarienrechnungen und Fallstudien zur Ozonanalyse im Berliner Raum mittels eines mesoskaligen Ausbreitungsmodells.

GMD First by order of the Senate Administration for Urban Development and Environmental Protection, Berlin

\section{Authors}

Prof. Dr. sc.nat. Bernd Stark

Technische Fachhochschule Wildau

Fachbereich Ingenieurwesen/Wirtschaftsingenieurwesen Tel.: (0049-3375) 504014

Dipl.-Met. Martin Lutz

Senatsverwaltung fir Stadtentwicklung, Umweltschutz und Technologie

Brückenstraße 6, D-10179 Berlin

z.Z. European Commission - Directorate General XI Environment, Nuclear Safety and Civil Protection Brüssel, Belgium

Tel.: (0032-2)296874 